\title{
The Influence of Jawa Post Publication and Group Involvement towards Public Participation in Surabaya Green And Clean (SGC) Program
}

\author{
Noorshanti Sumarah \\ Faculty of Political and Social Sciences, University of 17 Agustus 1945, Surabaya, Indonesia
}

Abstract

Environmental development in Surabaya is carried out through various programs inviting the public to participate in them. "Surabaya Green and Clean" is one of the programs. It involves the public and Jawa Post, a national newspaper, as a means to spread information. The study aims at testing the influence of publication and group involvement towards public participation in the program. Based on the hypothesis testing, it is concluded that publishing news about "Surabaya Green and Clean" in Jawa Post and group involvement have significant influence towards public participation in "Surabaya Green and Clean" Program.

Keywords: Public participation, Newspaper, Surabaya Green and Clean

\section{INTRODUCTION}

"Surabaya Green and Clean" is annual developmental program held by the regional government of Surabaya. It is a competition on all aspects related to environmental management among districts in Surabaya. Rewards are given to the winner of the competition. In "Surabaya Green and Clean," public and facilitators in each district in Surabaya prepare and run various programs and innovations that will give those head up in the competition. "Surabaya Green and Clean" is fully supported by Jawa Post, as means to spread news about the program. The newspaper devotes special column for "Surabaya Green and Clean" providing various information on registration, preliminary selection nominees, judging, and awarding. Jawa Post reports some preparations each district makes and the best program each of them has when "Surabaya Green and Clean" is running. Each district participating in the program has its turn to be published in the newspaper. Besides that, Jawa Post also publishes other information related to the implementation of the program to the public. The newspaper's support in delivering day-to-day news about "Surabaya Green and Clean" provides maximum exposure for facilitators and public in general. Another effect of Jawa Post massive coverage is that each district can find out its competitors plan and programs, and, as the effect, will pull out the best effort to win "Surabaya Green and Clean." In

Correspondence Address:

Noorshanti Sumarah

Email : shan_pm@yahoo.co.id

Address : Faculty of Political and Social Sciences, University of 17 Agustus 1945, Jl. Semolowaru 45 Surabaya 60118. conclusion, not only does Jawa Post publication on "Surabaya Green and Clean" provide clear information about the program to the public, but it also increases public motivation and participation in environmental management.

The effect of mass media towards individual behavior has been elaborated in various communication theories. Powerful effect Model [1] states that mass media can give an immediate effect towards an individual when the message is well-delivered. Based on the theory, mass media can have a significant impact towards big population. Newspapers as one type of printed mass media functions as a means to deliver information and affecting people [2]. However, each type of media has its distinctive impact to different group of people. In general, the strength of printed mass media lies in structure of delivered message and the media will have effect to only if it is read. When one does not read, such type of media is not going to do anything. When the researcher conducted interviews with the facilitators, it was found that one immediately inform their group when they reads articles about their district participation in Surabaya Green and Clean published in Jawa Post. On the other hand, Jawa Post publication about "Surabaya Green and Clean" triggers communication between facilitators and their groups or individuals within one group. Once a district's participation in the program is published by the newspaper, some people are going to borrow the newspaper from their neighbor or friends, while some others are buying it. The role of messenger sometimes starts by facilitators in each district and is continued to other people living in the district. Therefore, based on the fact the process of delivering message about "Surabaya Green 
and Clean" does not always occur directly from Jawa Post to the public. However, there is group involvement to deliver, comprehend and translate the news published in the newspaper. Therefore, message being delivered is not the sole factor that determines the effect of publication, dynamic of the public where the message being delivered is.

Jumanti [3] conducted a study about the effect of news about flood in East Kalimantan newspapers towards public environmental awareness in Temindung Permai, Samarinda. The finding of the study is that publishing the news about the flood in East Kalimantan newspapers has significant influence towards public environmental awareness. Another study [4] entitled The Role of Mass Media (Newspapers) Promoting Danau Dua Rasa (Labuan Cermin) in Berau, East Kalimantan. The descriptive study aims at promoting Danau Dua Rasa (Labuan Cermin) in Berau, East Kalimantan to the public. The finding shows that newspapers can only spread educational information about the lake; however it fails to show recreational aspects of the lake. Pelesir, a show in MNCTV, is the one that fulfill the task.

Another study entitled Analyzing the Effect of Health Show in PKTV towards Public Awareness in Sanitation conducted by Rochmad [5]. The finding shows that the health show in PKTV gives significant effect towards public sanitation awareness only to frequent viewers; seminars and other types of mass media give more significant effect to public awareness in sanitation.

Based on the finding of the study, the purpose of the study is to determine the influence of Jawa Post publication about "Surabaya Green and Clean" towards increasing public participation in "Surabaya Green and Clean and determine the influence of group involvement towards public participation in "Surabaya Green and Clean?".

\section{THEORTICAL DEFINITION}

\section{Behaviourism Approach}

Numerous theories have described how human behavior is formulated and projected. A well-known approach to describe human behavior is behaviorism. The theory states that environment is the most important element that shapes human behavior since environment is the place where human being learns. Using stimulusresponse model, behaviorism explains that individual behavior relies heavily on learning process that takes place in his/her environment as a stimulus $[6,7,8]$. Robbin [9] states that an individual can also learn based on the observation on other people's behavior or through listening to other people's experience as long as the stories are complete and detail. The process of learning based on observation or other people's experience is called social learning theory. There are four processes taking place when an individual learning process takes place through observation or experience. They are attention process, retention process, motor reproduction process and reinforcement process. Robb explains those processes as follow:

1. Attentional process. People only learn from a model when they recognize and pay attention to its critical features. We tend to be most influences by model that are attractive, repeatedly available, important to use or similar to us in our estimation

2. Retention process. A model's influence will depend on how well the individual remembers the model's action after the model is no longer readily available.

3. Motor reproduction process. After a person has seen a new behavior by observing the model, the watching must be converted into doing. This process then demonstrates that the individual can perform the modeled activities.

4. Reinforcement process. Individual will be motivated on exhibit the modeled behavior if positive incentives or rewards are provided. Behaviors that are reinforced will be given more attention, learning better and performed more often.

In line with Robbins, Bandura in Effendi [2] explain that social learning theory considers mass media as main social agent besides family, teachers and close friends. In social learning, paying attention is the first step. An individual will not learn unless he or she pays attention. One's attention depends on characteristics of an event and observer. A simple, clear and well-organized concept is going to attract people's attention, and, as the result, is easier to follow. The following step is retention process that is a where an interesting concept is drawn into one's brain and then formulated into memory. The third is motor reproduction process where memory is converted into behavior and the behavior will most likely 
become a habit when reinforcement is given. Reinforcement is in the form of internal or external motivation. Thus, the last face is called motivational process.

\section{Structural-Functional Approach}

Another approach similar to behaviorism is structural-functional approach; the theory also uses the influence of environment towards individual behavior as the underlying theory. Structural-functional approach states that a society consists of various elements that interact and influence one another. Each of the elements has its own function, and, therefore, when the function of an element changes, other elements is going to be affected as well [7].

Mass media is one of the stimuli affecting individual behavior. The influence of mass media towards a society is not only in the form of a message being delivered, but also the physical form of the mass media itself [10]. MacLuhan famous for his "the medium is the message" theory, states that mass media has such a major influence towards the society $[1,10]$. Chaffee mentions that the presence of mass media has influenced 5 (five) different aspects of the society namely (1) economics, (2) social, (3) schedule/ organization, (4) how people channel their feeling, and (5) people's impression towards media [10].

Experts in communication have also elaborated the impact of publication in mass media towards change in individual behavior. Bullet theory states that large scale publication will give an impact towards individual behavior [1]. Stimulusresponse model also mentions that reaction or individual behavior can be predicted based on messages being published in mass media [11].

Another theory that explains the impact of media towards individual behavior is diffusioninnovation theory. The theory is related to introduction of new ideas and elaborated by Rogers [1]. Rogers explain 5 (five) stages in diffusioninnovation, namely (1) knowledge, (2) persuasion, (3) decision, (4) implementation, and (5) confirmation. The first stage, knowledge, involves individual awareness towards innovation and his/ her understanding that the innovation can actually work. Persuasion stage is the process of formulating individual's opinion (agreement/ disagreement) towards an innovation. The following stage, decision, is the process on which a person makes a decision whether they are going to adapt an innovation. Implementation is the stage when an individual takes action based on the decision they had come up with. The final stage, confirmation, is the process when an individual seeks for a confirmation from others towards the decision they had made. During the stage, there is a possibility that an individual changes their decision if they think that information about the innovation they obtains is against their opinion.

Rogers state that change due to adoption and rejecting an innovation are two consequences diffusion-innovation theory has towards individual and society. The expert elaborates the consequences of the theory in a more detail manner.

1. Desirable versus undesirable, depends on whether or not innovation has functional or non functional effect towards individual or social system.

2. Direct versus indirect, depends on whether or not change in individual and social system takes place because of innovation direct response or innovation causal response from other responses.

3. Anticipated versus unanticipated, depends on whether or not change that occurs is expected or unexpected by group member.

Based on the statements above, one can draw conclusion that mass media have direct impact towards individual. However, many experts claim that the effect of mass media towards individual is not always a direct one. Liliweri [8] state several theories about selective influence of mass media to the society. It means there are some indirect effects of media towards society. Joseph Klapper's Limited Effect concludes that the effect mass communication have to society is not a direct one, instead mass communication works between mediatingfactors. Klapper further mentions the mediatingfactors are selective processes (selective perception, selective exposure, selective retention), group processes, group norm and opinion leader [1]. Meanwhile, Baran and Davis [12] conclude some important highlights of the limited effect theory, namely:

1. It is unlikely for media to have direct influence towards individual which means that family, friends, colleagues and social work protect an individual from being manipulated by the media.

2. There are two streams of influence of media. Media will be influential when opinion leader or a person directing their followers 
had been influenced. It is extremely difficult for media to manipulate sophisticated and critical opinion leader

3. When an individual is growing, they have a strong commitment to their group. The affiliation will give an effective barrier from the influence of media.

4. When the effect of media occurs, it usually is too weak or too specific. Affected individual is generally isolated from other people's influence or group commitment is getting weaker

\section{Limited Effect Model}

Based on limited effect model, it can be explained that one requirement for mass communication effect to work is group processes. Based on the opinion "Surabaya Green and Clean" publication will influence individual participation in "Surabaya Green and Clean" and the publication will also determine the individual involvement in group processes of their group. Based on the theories, conceptually, model of correlation based on theoretical framework of the study is as following Fig.1.

Based on stimulus-response theory, there are 3 (three) requirements for communication as stimulus to give response in the form of attitude and behavior, namely attention is paid to the message, message is comprehended and message is accepted. As an addition, Monroe message should be organized based on five sequential steps namely motivated sequence in order to be able to influence society; the five steps are attention, need, satisfaction, visualization and action [10]. Attention refers to how much atten- tion public pays to delivered message. Having been delivered, a message should trigger need and show how to fulfill the need. Next step is to provide an overview in public's mind what advantage or disadvantage they get when they implement or do not implement the message. Finally, public are encouraged to take action. When the steps have been fulfilled, there is a high possibility that message published by mass media changes public behavior.

Experts have discussed the correlation between individual and group behavior. In his study, Triplet concludes that the presence of other people or competitors has influence towards the performance of racers [14]. The presence of other people enhances individual performance. The experts also claim that the group influence towards individual performance has not always been positive; it can give negative influence as well. Similar phenomenon takes place in studies about problem-solving. It can be concluded solving problems in groups is more effective and productive than doing so individually [14]. Psychiatrists perceive group communication as a medium to increase mental health and ideologists consider it as a means to improve political-ideology awareness [10]. Further, Rahmat explains about conformity, that has correlation with the influence of group towards individual behavior [10]. When a number of people in a group says one thing or does the same thing, there is a tendency that member of the group to follow. It is evidence that group has huge impact towards individual behavior. Based on the review of the literature, the operational framework of the study is described in Fig. 2.

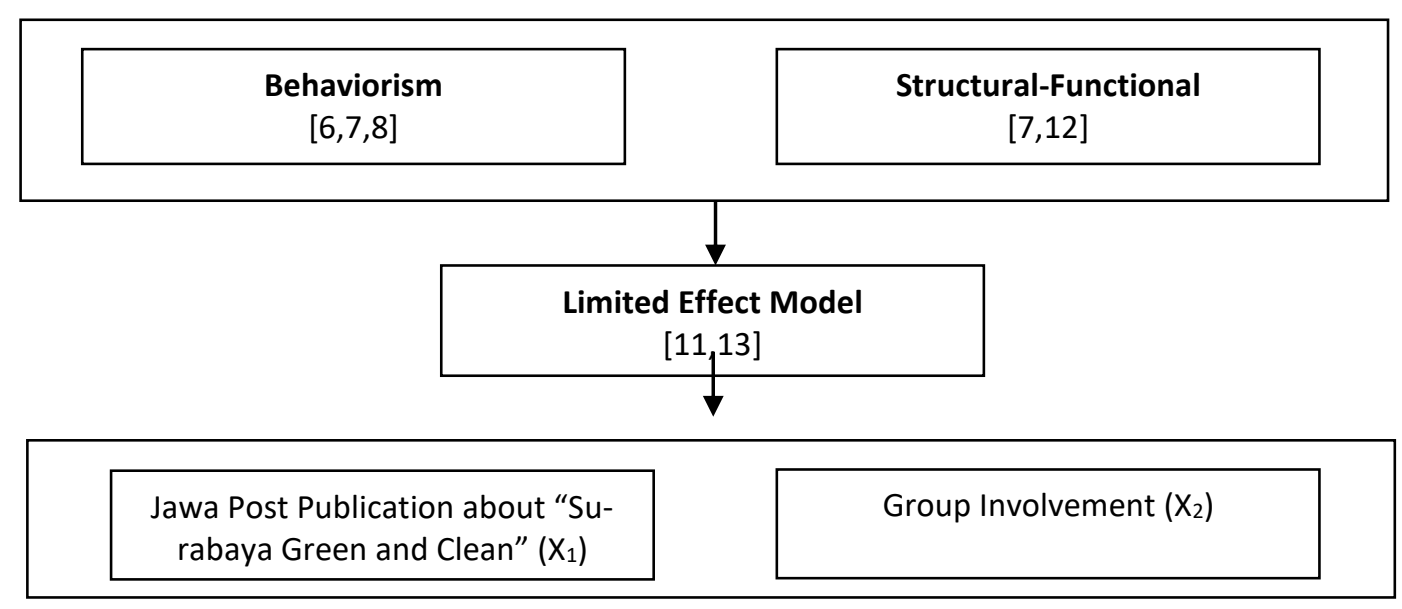

Figure 1. Model of Correlation based on Theoretical Framework of the Study 


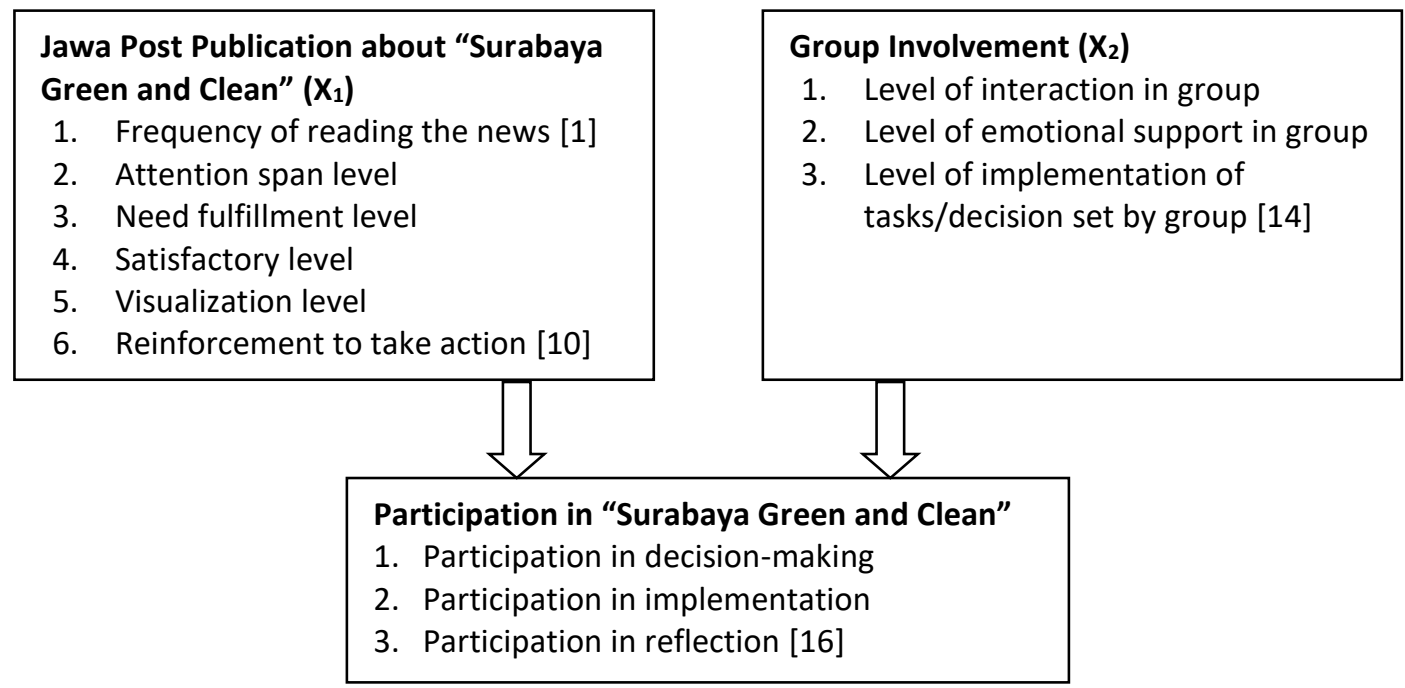

Figure 2. Operational Framework

Based on the review of the literature, the hypotheses of the study are formulated as follow:

Ho1: There is no significant influence between "Surabaya Green and Clean" publication toward public participation in the program

Ha1: There is a significant influence between "Surabaya Green and Clean" publication toward public participation in the program

$\mathrm{Ho}_{2}$ : There is no significant influence between group involvement and public participation in "Surabaya Green and Clean"

$\mathrm{Ha}_{2}$ : There is a significant influence between group involvement and public participation in "Surabaya Green and Clean"

\section{METHODOLOGY}

The study is an explanatory study that explains inter-variable influence. The number of samples are 100 (one hundred) respondents selected randomly from 6 (six) regions in Surabaya. The samples are readers of Jawa Post.

The definitions of the keywords, and variables, as well as their indicators, of the study are described as follow:

1. News is current information containing facts and opinion that attract public's attention

2. "Surabaya Green and Clean" is a competition in environmental management sector conducted by the regional government of Surabaya in collaboration with private parties

3. "Surabaya Green and Clean" news is current information containing facts and opinion that attract public's attention about a competition in environmental management sector conducted by the regional government of Surabaya in collaboration with private parties

4. Group involvement is individual involvement in an event conducted by two or more people in order to achieve certain goal

5. Participation is individual participation in decision-making, implementation, supervision and reflection in an event

6. "Surabaya Green and Clean" is an annual environmental management and sanitation program conducted by the regional government of Surabaya

The definition of operational variables and their indicators are as follow:

1. "Surabaya Green and Clean" publication in Jawa Post variable is measured by these indicators, namely:

a. Reading frequency, which means how many times one reads news about the program in the newspaper

b. Attention span, which means how much attention one pays to the news

c. Level of sufficiency, which means whether or not the news raise public's awareness toward environmental management

d. Level of satisfaction, which means whether or not the news provides in- 
formation about environmental management

e. Visualization, which means whether or not the news gives an overview about beneficial effect of environmental management

f. Implementation, whether or not the news gives motivation to conduct environmental management

2. Group involvement variable is measured by the following indicators, namely:

a. Interaction which means how much interaction a person makes to their group

b. Task which means how much one person fulfill a task given by their group

c. Responsibility which means how much responsibility a person has to support group task related to environmental management

3. Public participation variable is measured using the following indicators, namely

a. Individual participation in planning of "Surabaya Green and Clean" program in their district

b. Individual participation in the implementation of "Surabaya Green and Clean" program in their district

c. Individual participation in the reflection of "Surabaya Green and Clean" program in their district

\section{Data collection}

Data collection is conducted using questionnaire structurally designed based on the variables in the study. Other data collection methods are documentation and observations.

Karl Pearson's Product Moment analysis is used in data analysis. Alpha Cronbach using 0 to 1 scale is the method to measure the level of validity and reliability of the instrument. Finally, corrected item-total correlation is used to test item validity in the questionnaire.

\section{RESULTS AND DISCUSSION}

Having analyzed the data using Product Moment correlation through SPSS program, the findings of the study are described as follow:

1. Correlational coefficient between "Surabaya Green and Clean" publication variable or $\mathrm{X}_{1}$ and public participation in "Surabaya Green and Clean" variable or $Y$ is $0.689(\alpha=0.000)$. It means "Surabaya Green and Clean" publication or $X_{1}$ variable has significant influ- ence towards public participation in "Surabaya Green and Clean" or $Y$ variable.

2. The result of t-test of both $X_{1}$ and $Y$ variables is 12.9850 ( $r=0.698 ; \alpha<0.05)$. It means the influence of "Surabaya Green and Clean" publication or $\mathrm{X}_{1}$ variable towards public participation in "Surabaya Green and Clean" or Y variable is highly significant

3. Correlational coefficient between group involvement variable or $\mathrm{X}_{2}$ and public participation in "Surabaya Green and Clean" variable or $Y$ is 0.863 ( $\alpha=0.000$ ). It means group involvement or $X_{2}$ variable has significant influence towards public participation in "Surabaya Green and Clean" or Y variable.

4. The result of t-test of both $X_{2}$ and $Y$ variables is 33.4767 ( $r=0.863 ; \alpha<0.05)$. It means the influence of group involvement or $X_{2}$ variable towards public participation in "Surabaya Green and Clean" or $Y$ variable is highly significant

5. Correlational coefficient between "Surabaya Green and Clean" publication variable or X1 and group involvement variable or $X_{2}$ is $0.676(\alpha=0.000)$. It means "Surabaya Green and Clean" publication or $\mathrm{X}_{1}$ variable has significant influence towards group involvement or $\mathrm{X}_{2}$ variable

6. The result of t-test of both $X_{1}$ and $X_{2}$ variables is 9.0183 ( $r=0.676 ; \alpha<0.05)$. It means the influence of Surabaya Green and Clean" publication or $\mathrm{X}_{1}$ variable towards group involvement or $X_{2}$ variable is highly significant

Partial correlation test with group involvement or $X_{2}$ variable as is carried out to find out whether the influence of "Surabaya Green and Clean" publication or $\mathrm{X}_{1}$ variable towards public participation in "Surabaya Green and Clean" or $Y$ variable is a real or temporary one. Using SPSS program, partial correlational coefficient ( $\left.r x_{1} y . x_{2}\right)$ is $0.284(\alpha=0.004)$. Therefore, the effect of "Surabaya Green and Clean" or $\mathrm{X}_{1}$ variable towards public participation in "Surabaya Green and Clean" is real. The results of regression analysis on variables of the study are as follow:

1. Correlational coefficient between "Surabaya Green and Clean" publication or $\mathrm{X}_{1}$ variable and group involvement or $X_{2}$ variable to- 
gether with public participation in "Surabaya Green and Clean" or $Y$ variable is $r=0.875$; determination coefficient is $n^{2}=$ 0.765 which means $76.5 \%$ of public participation in "Surabaya Green and Clean" is explained by "Surabaya Green and Clean" publication and group involvement variables. The remaining $23.5 \%$ is explained by another variable. The regression equation can be explained as follow:

\section{$Y=1.675+0.403 X_{1}+1.060 X_{2}$}

2. From the analysis, it is found out that $F=$ 158.237 with probability rate $=0.000$. Therefore, the model is considered as a good model that can be implemented to predict public participation in "Surabaya Green and Clean."

Referring to the result of the analysis, the findings of the study are elaborated as (1) "Surabaya Green and Clean" publication variable has meaningful and significant influence, when there is no other variable; (2) With group involvement variable being the control variable, the influence of "Surabaya Green and Clean" publication variable towards public participation in "Surabaya Green and Clean" is getting smaller; (3) "Surabaya Green and Clean" publication variable together with group involvement has higher influence towards public participation in "Surabaya Green and Clean."

The statements above explain that there is a tendency that the influence of mass media towards public behavior will likely be more significant if mass media is combined with certain variables. The findings of the study is in line with the theories mentioned in the literature review that basically mass media gives more significant towards individual or public behavior when it works together with another/other variable(s). In the context of the study, group involvement $\left(X_{2}\right)$ is the variable. The findings of the study also support Joseph Klapper's theory that it is unlikely for mass communication to have direct influence society unless it is combined with other mediatingfactors. Klapper further mentions that selective processes (selective perception, selective exposure, selective retention), group processes, group norm and opinion leader [1] are some examples of mediating factors. The expert explains that drawing conclusion that media has zero in- fluence is rather inaccurate; instead media works in the existing social structure correlation in particular social and cultural context. Social and cultural factor plays important roles to generate individual choice, attention and response [17]. Mara't argues that a stimulus one get as the result of communication is going to be either accepted or rejected. Change in attitude as the effect of communication will take place if an individual pays attention to, understands and agrees with a message. If the process happens successfully, the individual will then have an awareness to change his/ her behavior. The theory gives an overview that a stimulus a person accepts does not change into response all at once; attention, comprehension and affirmation are three influential factors that determine whether or not a stimulus will turn into response. In line with the statement, Defleur argues that individual difference should be taken into consideration in finding out correlation between stimulus and response.

The expert, further, states that even though response can be observed clearly, the type of response are various based on the difference in personality, attitude, intelligence, interest and so forth. A message being delivered by mass media contains particular stimulus which has various different interaction with characteristics of audience personalities [17]. Similar to the theory, DeFleur in Effendi [2] comes up with social category theory. The theory also claims the presence of another/other factor(s) that determine direct influence of media. DeFleur explains that there are groups, meetings, and social categories in urban industrial society and the society has unanimous response (action) towards certain stimuli. Age, sex, income, education and the like determine media influence tremendously.

Bandura in Effendi [2] social learning theory is one of theories that state that the influence of media towards individual is not immediate. The expert argues that response, the result of learning, is determined by reinforcement, where an individual is going to repeat their response when reward is given. At the same time, the individual is not going to repeat their response when they get punishment or behavior designed externally by reinforcing conditions.

Meanwhile, Maletzke's Model state that basic elements in mass communication are message, medium and recipient. Based on the model, there are two components between medium and recipient which influence individual response, obstacle of the medium and the image medium 
for recipients or individual [11]. Obstacle of media is related to the fact that different media require different process of adaption from an individual. Each type of media has its own strength, weakness and characteristics that determine its influence toward an individual.

On the other hand, "image medium" component is related to prestige and credibility of medium. Besides the two components, other factors that determine mass communication process is individual concept, individual personality structure, individual membership in a group, and individual social environment.

Individual concept is related to individual perception of themself, their role, attitude and value they have. Personality structure is related to the fact that an individual with certain characteristics can be persuaded more easily compared to others. It is easier to persuade a person with low confidence than one with high confidence. Meanwhile, individual social context is related to environment where an individual is at. It is difficult to persuade an individual to accept a message conflicting with values of a group they belong to. Finally, individual membership in a group is related to the fact communication process taking place in groups is different from a face-toface communication. As a member of a certain group, an individual is not going to feel that they are alone in giving strong response to communication process that takes place.

The doubt of direct impact of media towards individual is also mentioned in Katz and Lazarfeld's two-step flow model of mass communication [8]. Based on the theory, an individual is a group member who has interaction with society and other groups. Mass media, basically, does not have immediate influence towards society or individual; instead it works through mediatingfactors and is heavily influenced by social interaction an individual has. Based on the theory, individual ability to digest information published in mass-media is different. There are groups of individuals who actively seek for information and are able to digest it quickly. On the other hand, some other groups need more time to do so. The second group relies heavily on their facilitators who plays important role in selecting, spreading information as well as helping the groups to understand the information. Most of the time, facilitators are sources of information. According to Katz, facilitators are those that use mass-media more frequently and become mentors and source of information.
Based on the explanation above, there are numerous theories about the doubt about direct influence of mass media towards individual and society. The findings of the study confirm that mass media (newspaper) seems to have immediate influence towards both individual and society when analyzed without another/other variable(s). However, correlational coefficient rate decreases when another/other variable(s) being involved. The findings of the study also conclude that influence of "Surabaya Green and Clean" publication towards public participation in "Surabaya Green and Clean" declines when group involvement variable is involved. In other words, the findings of the study confirm Joseph Klapper's Limited Effect Model confirming that mass media basically has limited effect towards society. Its existence will work along with several mediating factors; one of which is group process. Finally, the study enriches other studies more specifically those related to influence of message delivery through mass media towards public or individual.

\section{CONCLUSION}

Following conclusion drawn based on the data analysis, namely:

1. "Surabaya Green and Clean" publication in Jawa Post variable has significant influence towards public participation in "Surabaya Green and Clean" variable

2. Group involvement variable has significant influence towards public participation in "Surabaya Green and Clean" variable

3. "Surabaya Green and Clean" publication in Jawa Post variable has significant influence towards group involvement variable

4. The influence of "Surabaya Green and Clean" publication in Jawa Post towards public participation is bigger when it is combined with group involvement

5. The influence of mass media towards individuals or public will be higher when all variables work altogether

\section{SUGGESTIONS}

Based on the conclusions, the following suggestions are given:

1. To guarantee the success of government programs that involve mass media, another variable, such as group process, should be optimized 
2. To manage and maintain the success of environmental management program in Surabaya, there should be collaboration between mass media, public and regional government

3. Identifying other variables that contribute in improving the role of mass media in implementation of developmental programs and developing developmental design models involving mass media should be carried out

\section{REFERENCES}

[1]. Saverin, WJ and JW Tankard. 1996. Communication theories: origins methods and uses in the mass media. Longman Publishing Group, New York.

[2]. Effendi, OU. 1993. Dinamika komunikasi. PT Remaja Rosdakarya. Bandung. 278-282.

[3]. Jumanti, R. 2013. Pengaruh berita banjir di koran Kaltim terhadap Kesadaran Lingkungan Masyarakat Kelurahan Temindung Permai Samarinda. Bachelor Thesis. Mulawarman University, Samarinda.

[4]. Passallo. 2013. Peran media massa cetak (koran) dalam meningkatkan pariwisata Danau Dua Rasa (Labuan Cermin) Berau. Bachelor Thesis. Mulawarman University, Samarinda.

[5]. Rocmad. 2013. Analisis efek info tayangan kesehatan di PKTV Terhadap Kesadaran Masyarakat mewujudkan perilaku hidup yang bersih dan sehat. Bachelor Thesis. Mulawarman University, Samarinda.

[6]. Hall, CS and G Lindzey. 1995. Teori-teori sifat dan behaviouristik. Kanisius Publication. Yogyakarta. 199-203.

[7]. Littlejohn, SW. 1996. Theories of human communications. Wadsworth Publishing Company. Belmont, California. 14-25.

[8]. Liliweri, A. 1991. Memahami peran komunikasi massa dalam masyarakat. PT Citra Aditya Bakti. Bandung. 70-101.

[9]. Robbin, SP. 1993. Organizational behavior. Prentice Hall International Editions. Canada.

[10]. Rakhmat, J. 1994. Psikologi komunikasi, Edisi Revisi. PT. Rosdakarya. Bandung. 141297.

[11]. McQuail, D. and S Windahl. 1987. Communication models. Logman. London and New York.

[12]. Baran, SJ and DK Davis. 2010. Teori dasar komunikasi massa: dasar, pergolakan dan masa depan. Salemba Humanika Publication. Jakarta. 177.

[13]. Mar'at. 1981. Sikap manusia perubahan serta pengukurannya. PT Ghalia Indonesia. Jakarta.

[14]. Walgito, B. 2006. Psikologi kelompok. Andi Publication. Yogyakarta. 4-5.

[15]. Goldberg, AA and CE Larson. 1985. Komunikasi kelompok proses proses diskusi dan penerapannya. UI Press. Jakarta.

[16]. Bryant, C and LG White. 1982. Manajemen pembangunan untuk negara berkembang. LP3ES, Jakarta. 274-276.

[17]. McQuil, D. 1987. Teori komunikasi massa. Penerbit Erlangga. Jakarta. 229-235. 